\title{
CONSERVATIVE PHYSICAL EDUCATION FOR RADICAL POLITICS: THE EXAMPLE OF FIDEL CASTRO
}

\author{
EDUCAÇÃO FÍSICA CONSERVADORA PARA POLITICA RADICAL: \\ O EXEMPLO DE FIDEL CASTRO
}

\author{
EDUCACIÓN FÍSICA CONSERVADORA PARA POLÍTICA RADICAL: \\ EL EJEMPLO DE FIDEL CASTRO
}

\section{Alan Bairner*}

\section{Keywords}

Fidel Castro. Physical Education. School Sport. Revolution.

Palavras-chave

Fidel Castro. Educação Física. Esporte na Escola. Revolução.

\section{Palabras clave}

Fidel Castro

Educación Física. Deporte en Escuela. Revolución.
Abstract: This essay examines the thoughts on sport and physical education of Fidel Castro who, on occasions, spoke like a nineteenth-century English private school educator in the muscular Christian tradition. I argue that, although we normally think of public intellectuals as traditional scholars who contribute to public debates, there is an unarguable case for considering the ideas of public figures who are also organic intellectuals in the Gramscian sense. With this in mind, the main focus of this particular study is on Castro and his views on subject matter that might initially appear to be outside his normal sphere of interest or his primary public remit.

Resumo: Este ensaio analisa os pensamentos sobre esporte e Educação Física de Fidel Castro, que, em certas ocasiões, falou como um educador inglês de escola privada do século XIX, dentro da tradição cristã muscular. Defendo que, embora costumemos pensar sobre os intelectuais públicos como estudiosos tradicionais que contribuem para debates públicos, há um argumento indiscutível para se considerarem as ideias de figuras públicas que também são intelectuais orgânicos no sentido gramsciano. Com isso em mente, este estudo específico tem seu foco principal em Fidel Castro e suas visões sobre um tema que, em princípio, pode parecer fora de sua esfera normal de interesse ou de suas principais preocupações públicas.

Resumen: Este ensayo analiza los pensamientos sobre deporte y educación física de Fidel Castro, que, en ciertas ocasiones, habló como un educador inglés de escuela privada del siglo XIX, dentro de la tradición cristiana muscular. Defiendo que, aunque generalmente pensemos sobre los intelectuales públicos como estudiosos tradicionales que contribuyen para debates públicos, hay un argumento indiscutible para que se consideren las ideas de figuras públicas que también son intelectuales orgánicos en el sentido gramsciano. Con esto en mente, este estudio específico tiene su foco principal en Castro y sus visiones sobre un tema que, en principio, puede parecer fuera de su esfera normal de interés o de sus principales preocupaciones públicas.
* School of Sport, Exercise and Health Sciences, Loughborough University, Loughborough, Leicestershire, LE11 3TU, United Kingdom. Email: A.E.S.Bairner@lboro.ac.uk

Recebido em: 06-06-2014 Aprovado em: 10-09-2014 (c) (i) () Licence 


\section{INTRODUCTION}

According to Carter (2014, p. 1), "sport is often a conservative set of institutional practices used to reinforce existing power relations". It has certainly tended to be associated far more with conservative values, such as tradition, than with radical politics. Furthermore, much of the progressive academic literature on sport and physical education in schools has concentrated on the importance of inclusion rather than competition, particularly in relation to young people with a disability or to students with learning difficulties (HAYCOCK; SMITH, 2010). Yet there is no reason why conservative approaches to a variety of human activities cannot be intrinsically progressive or, at the very least, serve a progressive social agenda. There is arguably a mistaken belief that "the didactic teacher is assumed to correspond to the political dictator applying censorship to the media of communication, telling people what they ought to think and employing repressive disciplinary methods to ensure that there is no expression of opinion or political activity unfriendly to the regime" (ENTWISTLE, 1979, p. 87). Yet, commenting on the Italian Marxist Antonio Gramsci's ideas about schooling, Entwistle (197, p. 3-4) argues that "far from the paradox of Gramsci's political radicalism and educational conservatism being one of his 'creditable inconsistencies', his writing in fact reveals a coherent socio-pedagogic theory of relevance to anyone interested in radical social change". With this in mind and with specific reference to physical education, it should not come as a total surprise, therefore, that in one of his earliest publications, Mao Zedong (1917) sounds more like a nineteenth-century English public school headmaster than a future communist leader, arguing that "when the body is strong, then one can advance speedily in knowledge and morality, and reap far-reaching advantages". This essay examines the thoughts on sport and physical education of another major revolutionary leader, Fidel Castro, who on occasions also spoke like a private school educator in the muscular Christian tradition which, during the late 1850s in England, became an integral part of the public (i.e. private) education system (WATSON et al., 2005). In the essay, I argue that although we normally think of public intellectuals as traditional scholars who contribute to public debates, there is an unarguable case for considering the ideas of public figures who are also organic intellectuals in the Gramscian sense, not least in order to challenge what is commonly regarded as progressive wisdom. Thus, the main focus of this particular study is on Castro and his views on subject matter that might initially appear to be outside his normal sphere of interest or his primary public remit.

\section{ESTABLISHING CASTRO'S CREDENTIALS AS A PUBLIC INTELLECTUAL}

The public intellectual, according to Posner (2003, p. 23), "writes for the general public, or at least for a broader than merely academic or specialist audience, on 'public affairs' - on political matters in the broadest sense of that word, a sense that includes cultural matters when they are viewed under the aspect of ideology, ethics, or politics (which may all be the same thing)". Lightman (2004) identifies three levels of public intellectualism. The first involves writing for the public exclusively about one's own discipline. The second concerns speaking and writing about one's own discipline and how it relates to the social, cultural, and political world around it. The highest level is "by invitation only" and allows the intellectual - in this instance Fidel Castro - to stand for something larger than the discipline or activity from which he or she first emerged. 
Antonio Gramsci's general theory, and in particular his concept of hegemony, has been regularly used (and abused) within the sociology of sport (see BAIRNER, 2009a). However, his work on intellectuals has received much less attention. Yet, as Salamini (1981, p. 101) asserts, "Gramsci's analysis of the role of intellectuals... represents one of the most creative developments in the history of Marxist theory". According to Gramsci (1971, p. 9), "all men are intellectuals...but not all men have in society the function of intellectuals". He continues, "there is no human activity from which every form of intellectual participation can be excluded: homo faber cannot be separated from homo sapiens" (p. 9). Non-intellectuals simply do not exist. On the other hand, only certain intellectuals appear to possess or be assigned the traditional qualities that give them the right or, at the very least, accord them the potential to become public intellectuals. The type of knowledge that permits one to become a public intellectual and/or to enter into public debate is, of course, specialised; but not all forms of specialist knowledge are regarded as equal. However, for Gramsci intellectuals are, in the words of Crehan (2002, p. 131), "not merely those who think, but those whose thoughts are considered to have a certain weight and authority". Moreover, specialist knowledge that may have little or no authority in one context may be massively influential in another.

Traditional intellectuals - academics, teachers, clerics, artists - fulfil functions that transcend particular historic conditions although they are able to work on behalf of or in opposition to the status quo in any given era (GRAMSCl, 1971). Organic intellectuals, on the other hand, are tied to specific periods and to specific social groupings that operate within those periods (GRAMSCI, 1971). This alone should alert us to the fact that there is nothing intrinsically subversive about organic intellectuals. Bankers, accountants and investment managers can be described as organic intellectuals of the capitalist epoch who serve (or, at least, try to serve) the interests of the economically powerful. Alternatively, organic intellectuals may be tied to subaltern groups in society. Not all of their ideas and actions are necessarily enlightened. From time to time, however, they provide the essential intellectual leadership that can benefit such groups and which cannot be given by traditional intellectuals alone. In the case of Fidel Castro, we find an educated organic intellectual, a revolutionary leader and statesman who also sometimes took time to comment on subjects that might normally be beyond the purview of most politicians. In the world of sport, and certainly in those parts of the world of sport in which working-class influence and radical political ideas remain significant, it is arguably comparatively rare that voices of authority, such as that of Castro, are to be heard. That is not to suggest, however, that his views on sport and physical education were as inherently progressive as some might either hope or imagine.

\section{PUBLIC INTELLECTUALS, SPORT AND PHYSICAL EDUCATION}

The relationship with those individuals and organisations that sociologists of sport quite often wish to critique is complex. For example, Lenskjy (2008) correctly cautions that becoming too closely involved with governing bodies creates difficulties and, thus, suggests that there is much to be said for being an outsider. However, as Vaugrand (2001, p. 190) notes, "the difficult task for critical theory of sport is to have access to every potential source of data". Perhaps then it is better to be seen as a critical friend as opposed to a hostile enemy (BAIRNER, 2009b). As Carrington (2007, p. 59) notes, "the need to 'fight' and the requirement to 'understand' are not mutually exclusive activities". I would add, however, that through understanding there comes 
an awareness of our own strengths and weaknesses in relation to the fight and an appreciation of the combative strengths of others. That said, as Michael (2000, p. 61) argues, "while there is no necessary or organic link between the professional work of cultural critics and any particular practical politics, the links that one can forge may become very real indeed". This is highly apposite in relation to influencing public debate.

Given the ongoing distrust of sports people for intellectuals and vice versa, even if the sociologist of sport's pronouncements are morally just, for them to receive a hearing it is essential that additional work is carried out amongst those people who will be most affected by certain policy decisions. That work is, in my view, virtually impossible for academics to conduct alone, even if we were not imprisoned by the current stage of development in our institutions of higher education. It is difficult, if not impossible, for us to change popular attitudes without appearing to be talking down to and at a distance from the very people whom we wish to influence (ROSS, 1989). According to Michael Burawoy (2007, p. 11), C. Wright Mills had a vision of a traditional public sociologist, "standing outside and above society refusing to have any direct connection to it". Gramsci, on the other hand, "never lost faith in the possibility of retrieving the good sense buried within common sense, a good sense that intellectuals could elaborate through their connection with the popular classes" (p. 11). This explains the need for organic intellectuals to help public sociology convey important messages to multiple publics. Indeed, it is engagement with organic intellectuals that can help critical sociologists of sport to avoid the distortion and misunderstanding which Talcott Parsons feared would accompany increased popular consumption of sociology (see HOLMWOOD; SCOTT, 2007). Anti-intellectualism, in Gramsci's view, flourishes where there is an absence of "a nexus between intellectuals and the masses" (SALAMINI, 1981, p. 121). Without the assistance of organic intellectuals, and the nexus which they can provide, our words will regularly fall on deaf ears. Furthermore, unless we can persuade those organic intellectuals, such as the ones discussed in this article, that we are pro-sport, their ears will also remain deaf to our more public pronouncements. It is in this respect that Castro's ideas are most useful and most provocative.

\section{CASTRO, PHYSICAL EDUCATION AND SPORT}

It is difficult to determine how we might classify Fidel Castro in relation to Gramsci's theory of intellectuals. An educated man, he came to prominence not as an intellectual but as a revolutionary fighter and longstanding political leader of global significance. Nevertheless, his thoughts on religion and specifically on the relationship between Marxism and liberation theology have been subject to analysis (CASTRO; BETTO, 2006). His ideas about sport and physical education, on the other hand, have received rather less prominence.

As Bailey (2005, p. 72) notes, "there is a close relationship between physical education and sport, but they are not synonymous". However, when Fidel Castro refers to physical education, it would appear that he almost always has sport in mind. He recalls that, as a boy, he "had had no conflict at Dolores College" (CASTRO; BETTO, 2006, p. 108). However, he decided for himself that we wanted to be transferred to Belén College, a Jesuit school with excellent facilities which was "attended by the cream of the aristocracy and the Cuban bourgeoisie" (CASTRO; BETTO, 2006, p.108). According to Castro, "the Jesuits spirit of self-sacrifice and austerity, the kind of life they led, their work and effort made a school of that caliber possible..." (CASTRO; 
BETTO, 2006, p. 109). It was, he remembers, "a wonderful school" with "several basketball courts, baseball fields, track and field facilities, volleyball courts, and even a swimming pool" (CASTRO; BETTO, 2006, p. 109). Castro had just turned sixteen at the time and quickly began to take an active part in school sport, claiming later that he was quite good at basketball, soccer, baseball and track and field - indeed "nearly everything" (CASTRO; BETTO, 2006, p. 109). This emphasis on competitive achievement is certainly worth noting. Like Mao, however, Castro also believed that "physical exercise and participation in sports can teach us a lot: rigor, endurance, determination, and self-discipline' (CASTRO; BETTO, 2006, p. 118). Interestingly, he makes this observation within the context of a more general appreciation of the Spanish Jesuits and their approach to education - regardless of their political views. Castro claimed that his temperament, which was "partly inborn, was also forged by the Jesuits" (CASTRO; RAMONET, 2008, p. 67). The Jesuits for their part were equally generous in return, describing Castro in the school yearbook on the occasion of his graduation from Belén as "an outstanding athlete always courageously and proudly defending the school's colors" (cited in CASTRO; BETTO, 2006, p. 240). Castro himself believed that the Jesuits made kind remarks about him because he was good at sports (COLTMAN, 2003).

It should be added that there was nothing peculiar about Catholic teaching orders adopting muscular Christianity, a term perhaps more commonly associated with Protestant educational establishments in nineteen-century England. In its commitment to sport, what was true of Belén College was equally true of Jesuit institutions such as Clongowes Wood in Ireland, alma mater of James Joyce (SUGDEN; BAIRNER, 1993), and Christian Brothers' establishments in Australia such as St. Charles's in Sydney and St. Patrick's in Goulbourn (see BAIRNER, 2007, 2009c). Castro admitted to having liked "the kind of healthy, austere life" he lived in those schools (CASTRO; RAMONET, 2008, p. 67).

Despite suffering from asthma, Castro's fellow revolutionary, Ernesto "Che" Guevera exhibited a similar enthusiasm for a variety of sports - swimming, soccer, rugby, golf and also chess (PARRISH, 2014). After Guevera was killed in Bolivia in 1967, Castro gave a speech in which he described his fallen comrade as "the man of ideas and the man of action" (CASTRO, 1968, p. 22). Indeed, Guevara (1961, p. 48) himself had written that the guerrilla fighter needs "a series of physical, mental, and moral qualities", not unlike those that Castro believed he had acquired in the course of a Jesuit education.

It is scarcely surprising, therefore, in light of the foregoing, that in the years immediately following the Cuban revolution, Castro and his comrades were keen to build sports and recreational facilities, providing access to all. Indeed, as Carter (2014, p. 7) notes: "the 1976 Cuban constitution, modelled on the earlier short-lived 1933 revolutionary constitution, clearly enshrined sport into this reshaped Cuban society". According to Carter (2014, p. 8), Castro and his colleagues "saw sport as a vital for the inculcation of revolutionary and socialist values". In addition, the symbolism and practice of sport allowed them "to demonstrate their 'natural' Cubanness as means of legitimating their usurpation of the existing order while also indicating the new order of things". Carter (2014, p.7) also refers to the revolutionaries' "almost puritanical values" but does not go on to consider the implications of this.

In fact, in the case of Castro, what comes to light are essentially what might generally be regarded as conservative views about the value of sport. Although this is not quite so apparent in Guevara's thinking, some of the sports about which he was most enthusiastic might seem 
unusual for a future revolutionary leader. These included golf and rugby. With reference to the former, Parrish (2014, p. 4) argues that "the socialisation the golf club provided [to] Guevara was not restricted to a cultural indoctrination of Córdoba's high society. On the contrary, the most meaningful relationships he developed in the golf club were with individuals of modest means whose purpose was specifically related to labor". The fact remains, however, that his access to these sports had been eased because of his relatively privileged background. Thus, it was almost certainly only his interest in football that allowed him to engage in a sporting context with working-class South Americans on a more equal footing. There is a story, perhaps apocryphal, that J. D. Bernal - scientist, communist and public intellectual (CHATTERJEE, 2011) - claimed that during the 1920s, as a member of the Communist Party of Great Britain, he was instructed to study football and cricket so that he could converse with members of the working class. Similarly, on his travels around Peru and Colombia, Guevara and his friend Alberto Granado organised football matches, and the sport itself "provided an opportunity to build rapport and gain the trust of those who looked upon the 'peculiar travelling doctors from Argentina' with scepticism" (PARRISH, 2014, p. 5).

\section{CONCLUSION}

It might seem ironic that the Cuban revolutionaries and others have been willing to embrace the intrinsically conservative activity of competitive sport (even though one might argue that, having attained power, they have used sport in much the same way as other established regimes). Amongst revolutionaries, Fidel Castro was certainly by no means alone in his regard for sport and physical education. Mao Zedung has already been mentioned in this respect and, in 1917, Lenin advocated the establishment of a High School for Sport and Physical Culture, believing that mass participation in sport could help in the creation of the new "communist man" (BUNCK, 1994). With specific reference to Cuba, Parrish (2014) argues that "Guevara's sport and leisure experiences, more than simply 'forming a bitter sense of humour', significantly contributed towards his development and revolutionary accomplishments". Indeed, as Carter (2014) demonstrates, "sport became a principal mechanism for inculcating the revolutionary ethos and imagined Cuban revolutionary". With this in mind, it is ironic that when sociologists of sport succeed from time to time in achieving the status of public intellectual, many of them are inclined to offer a critique of such phenomena as school sport and old-fashioned sport pedagogy. The lesson might be that social revolution cannot be placed in the hands of well-intentioned liberals. Rather it is the voices of determined organic intellectuals that we need to heed.

Describing Gramsci's attitude to pedagogy, Entwistle (1979, p. 53) comments that "the emphasis which he placed upon instruction, and his rejection of the notion that school learning can be spontaneous or natural, inevitably commits him to a conception of schooling as work". Thus, he emphasised the "importance of discipline, drill and method in learning" (p. 54). Indeed, Entwistle (1979, p. 170) continues, "anachronistic, as Gramsci took the classically oriented curriculum to be, he believed that quite aside from its cultural content, it 'satisfies a whole series of pedagogic and psychological requirements' (GRAMSCI, 1971, p. 38) which, by implication, would need to be met by any curriculum which might replace it". We should not ignore the fact that ill health prevented Gramsci from taking part in sport and that his public contribution was almost exclusively theoretical, a prime focus being on the intellectual worth of disciplined education. Castro, on the other hand, was both a theorist and a soldier. Unsurprisingly, there- 
fore, he commented favourably on the military spirit and military organization of the Jesuits. $\mathrm{He}$ noted that the founder of the order, St Ignatius Loyola was a soldier and suggested that "the Spanish Jesuits know how to inculcate a great sense of personal dignity in a boy, the sense of personal honour - they appreciate character, honesty, straight-forwardness, uprightness, a person's courage, his ability to make sacrifices" (CASTRO; RAMONET, 2008, p. 67). Elsewhere Castro remarks that "recently, some of the most rebellious personalities, such as the priests at the University of El Salvador and other [priests] have been Jesuits, very courageous men who've even given their lives" (CASTRO; RAMONET, 2008, p 66). This emphasis by Castro on muscularity might seem odd given that the muscular Christianity tradition is usually regarded as a conservative doctrine. As Mangan (1996, p. 28) noted, "the late nineteenth- and early twentieth century gentleman was essentially the product of the public school and its obsession with games and the games-fields as the heart of the curriculum, the source of masculine virtue and the instrument of imperial domination". Yet there is nothing inevitable about this association for as Kidd (2006, p. 701) points out, "whereas muscular Christianity is often associated with right-wing political ideas and fundamentalist Christian churches today, in Canada it was linked through the social gospel to the left".

Bunck (1994, p. 219) argues that the Cuban leaders "impressively succeeded in their attempts to create different popular attitudes toward sport". Although this is undeniable, the fact remains that this was achieved in large part by adopting what many would regard as a conservative understanding and valorisation of sport. As Bunck (1994, p. 186) suggests, "Cuban leaders seized upon sports training as an opportunity to regiment and educate the population politically". To what extent, one is left to ponder, does this depart from the use of sport in most capitalist countries? The accuracy of Sanchez's (2014) recent expose of Castro's opulent lifestyle is a matter for conjecture. It is worth noting, however, that amongst the facilities that Sanchez informs us were located in his former employer's estate were a rooftop bowling alley and a basketball court, no doubt a powerful reminder of time spent at Belén College.

In sum, I have argued that revolutionary leaders such as Fidel Castro can legitimately be described as organic intellectuals. They are, of course, public figures as well. In addition, when they pronounce on subjects that are only tangentially linked to politics, they also acquire the status of public organic intellectuals. It is in this guise that Castro and others have revealed relatively conservative attitudes towards sport and physical education. As Entwistle (1979, p. 44) argued, "Marxists like Lenin and Gramsci could not have called for an alliance of intellectuals and workers.... if they dismissed traditional culture as bourgeois, in the sense of being 'false' or irrelevant to the needs of the working class". Following Entwistle's analysis of Gramsci's pedagogy, therefore, we may conclude that what Castro advanced was conservative physical education for radical politics.

\section{REFERENCES}

BAILEY, Richard. Evaluating the relationship between physical education, sport and social inclusion. Educational Review, Edinburgh, v. 57, n.1, p. 71-90, 2005.

BAIRNER, Alan. Wearing the Baggie Green: the Irish and cricket in Australia. Sport in Society, London, v. 10, n. 3, p. 457-475, 2007.

BAIRNER, Alan. Re-appropriating Gramsci: Marxism, Hegemony and Sport. In: CARRINGTON, B.; MCDONALD, I. Marxism, Cultural Studies and Sport. London: Routledge , 2009a. p. 195-212. 
BAIRNER, Alan. Sport, Intellectuals and Public Sociology: obstacles and opportunities. International Review for the Sociology of Sport, Warsaw, v. 44 n. 3/4, p. 115-130, 2009b.

BAIRNER, Alan. Irish Australians, postcolonialism and the English game. Sport in Society, London, v. 12, n. 4/5, p. 482-495, 2009c.

BUNCK, Julie Marie. Fidel Castro and the Quest for a Revolutionary Culture in Cuba. University Park, Pennsylvania: The Pennsylvania State University Press, 1994.

BURAWOY, Michael. Public sociology: Mills vs. Gramsci. Sociologica, Mexico, v.1, p. 7-13, 2007. Available: http://www.sociologica.mulino.it/doi/10.2383/24214. Accessed: 7 apr. 2009.

CARRINGTON, Ben. Merely Identity: Cultural Identity and the Politics of Sport. Sociology of Sport Journal, Champaign, v. 24, n.1, p. 49-66, 2007.

CARTER, Thomas F. Game Changer: The Role of Sport in Revolution. International Journal of the History of Sport, Uppsala, v. 31, n. 7, p. 735-746, 2014. DOI: 10.1080/09523367.2014.901759.

CASTRO, Fidel. In Tribute to Che. In: CHE GUEVARA. Reminiscences of the Cuban Revolutionary War. London: Allen and Unwin, p. 15-27, 1968.

CASTRO, Fidel; BETTO, Frei. Fidel Castro and Religion. Fidel Castro in conversation with Frei Betto on Marxism and liberation theology. Melbourne: Ocean Press, 2006.

CASTRO, Fidel; RAMONET, Ignacio. Fidel Castro: My Life. London: Penguin Books, 2008.

CHATTERJEE, S. Scientist as Revolutionary. Frontline, v. 18 n. 10, 2001. Available: http://www.frontline.in/static/htm//fl1810/18100860.htm. Accessed: 7 may 2014.

COLTMAN, Leycester. The Real Fidel Castro. New Haven: Yale University, 2003.

CREHAN, Kate. Gramsci, Culture and Anthropology. Berkeley: University of California, 2002.

ENTWISTLE, Harold. Antonio Gramsci: Conservative Schooling for Radical Politics. London: Routledge and Kegan Paul, 1979.

GRAMSCI, Antonio. Selections from the Prison Notebooks. London: Lawrence \& Wishart, 1971.

GUEVARA, Che. Guerrilla Warfare. New York: Monthly Review, 1961.

HAYCOCK, David; SMITH, Andy. Inclusive physical education? A study of the management of national curriculum physical education and unplanned outcomes in England. British Journal of Sociology of Education, Oxfordshire, v. 31, n.3, p. 291-305, 2010.

HOLMWOOD, John; SCOTT Sue. Editorial Foreword: Sociology and its Public Face(s). Sociology, Oxford, v. 41, n. 5, p.779-783, 2007.

KIDD, Bruce. Muscular Christianity and value-centred Sport: The Legacy of Tom Brown in Canada. International Journal of the History of Sport, Uppsala , v. 23, n. 5, 701-713, 2006.

LENSKYJ, Helen J. Olympic Industry Resistance. Albany, NY: State University of New York, 2008.

LIGHTMAN, Alan. The Role of the Public Intellectual. MIT Communications Forum, 4p., 2004. Available: http://web.mit.edu/comm-forum/papers/lightman.html. Accessed: 5 Sept., 2008.

MANGAN, J. A. 'Muscular, militaristic and manly': the British middle-class hero as moral messenger. International Journal of the History of Sport, Uppsala , v. 13, n. 1, p. 28-47, 1996.

MICHAEL, John. Anxious Intellectuals. Academic Professionals, Public Intellectuals and Enlightenment Values. Durham, NC: Duke University, 2000.

PARRISH, Charles. Building Character and Socialising a Revolutionary: Sport and Leisure in the Life of Ernesto "Che" Guevara. International Journal of the History of Sport, Uppsala, v. 31, n. 7, p. 747-759, 2014. DOI: 10.1080/09523367.2014.901757. 
POSNER, Richard. Public Intellectuals: a Study of Decline. Cambridge, MASS: Harvard University, 2003.

ROSS, Andrew. No Respect: Intellectuals and Popular Culture. New York: Routledge, 1989.

SALAMINI, Leonardo. The Sociology of Political Praxis: an Introduction to Gramsci's Theory. London: Routledge and Kegan Paul, 1981.

SANCHEZ, Juan Reinaldo La Vie Cacheé de Fidel Castro. Montréal: Michel Jafon, 2014.

SUGDEN, John; BAIRNER, Alan. Sport, Sectarianism and Society in a Divided Ireland. Leicester: Leicester University, 1993.

VAUGRAND, Henri. Pierre Bourdieu and Jean-Marie Brohm: Their Schemes of Intelligibility and Issues towards a Theory of Knowledge in the Sociology of Sport. International Review for the Sociology of Sport, Otago, v. 36, n.2, p.183-201, 2001.

WATSON, Nick J., WEIR, Stuart and FRIEND, Stephen. The Development of Muscular Christianity in Victorian Britain and Beyond. Journal of Religion and Society, Omaha, v. 7, 2005. Available: http:// moses.creighton.edu/jrs/2005/2005-2.pdf. Accessed: 16 aug. 2014.

ZEDONG, Mao. A study in physical education. Hsin ching-nein, Shanghai, apr., 1917. Available: http://www.marxists.org/reference/archive/mao/selected-works/volume-6/mswv6 01.htm. Accessed: 13 Dec. 2010. 


\section{Endereço para correspondência:}

School of Sport, Exercise and Health Sciences

Loughborough University, Loughborough 